\title{
Multilateral Aspects of Managing the Capital Account ${ }^{1}$
}

\author{
Jonathan D. Ostry ${ }^{*}$, Atish R. Ghosh, and Anton Korinek
}

\begin{abstract}
The financial crisis has again brought home the profound financial linkages across countries, often manifest in highly volatile capital flows. This volatility has prompted interest in multilateral principles to guide policies in both source and recipient countries. This paper discusses the analytical underpinnings of such principles, and attempts to draw implications from the analytics for the desirability of multilateral coordination of country policies. We argue that the global welfare implications of capital account regulations, or policies that mimic their effects, are threefold. First, spillovers from such policies do not necessarily have normative implications: if policies are justified from a national standpoint (in terms of reducing domestic distortions), under a range of conditions they should be pursued even if they give rise to cross-border spillovers. Second, however, if policies in one country exacerbate existing distortions in other countries, and it is costly for other countries to respond, then multilateral coordination of unilateral policies is likely to be beneficial. Third, coordination may require borrowers to reduce inflow controls or, much thornier, agreement by lenders to partially internalize the risks from excessively large or risky outflows.
\end{abstract}

*Corresponding author: jostry@imf.org

\footnotetext{
${ }^{1}$ We thank Olivier Blanchard, Marcos Chamon, Raphael Espinoza, and David Lipton for helpful comments on earlier versions of this paper, and Jane Haizel for assistance. Views expressed are the authors' and should not be attributed to the IMF.
} 


\section{INTRODUCTION}

The financial crisis has again brought home the profound financial linkages across countries, often manifest in highly volatile capital flows. During the 2008 global financial crisis, capital flows to emerging market economies (EMEs), which had peaked at $\$ 665$ billion in 2007, plummeted to less than $\$ 170$ billion in 2008, only to surge again in 2010 as the global recovery got underway. Following the US sovereign downgrade, capital flows to EMEs again dried up, then resumed, and have been bouncing around quite a bit ever since. This volatility, as well as the policy responses of EMEs attempting to cope with the macroeconomic and financial-stability challenges wrought by swings in capital flows, has prompted interest in a set of principles that could guide policy in both capital-source and capital-recipient countries. This note discusses the analytical underpinnings, and possible contours, of such principles.

A first question is how an individual country, acting in isolation, should respond to a surge of capital inflows. This question has been the subject of several recent papers by the Fund, including on the use of monetary, exchange rate, and intervention policies; capital controls; and prudential regulation of domestic banks (Ostry et al., 2010, 2011, and 2012; and IMF, $2011 \mathrm{a}$ and $\mathrm{b}$ ). The underlying premise is that there exists some distortion in the domestic economy (such as excessive foreign borrowing (see Korinek, 2010, 2011), or a learning-bydoing externality in the production of exportables) that is exacerbated by the capital inflow. While the ultimate goal may be to improve the economy's resilience to financial-stability risks, the short-term response may call for restricting the volume of inflows or mitigating the risks associated with them, the precise instrument depending on specific circumstances.

This note provides further analysis of the possible multilateral consequences of country policies, and of the desirability of multilateral coordination to secure globally efficient outcomes. Three issues are of concern. First is the possibility that capital controls may have the effect of vitiating or preventing external adjustment, for example when inflow controls are used to sustain an undervalued currency. Second, as each capital-receiving country that faces excessive capital flows seeks to reduce its own inflows in support of domestic financial stability, it may deflect some capital flows towards other recipient countries, exacerbating their inflow problem. Third, policies in source countries, to the degree they increase the volume of capital flows, may aggravate problems faced by capital-receiving countries.

Empirical evidence on deflection between capital-receiving countries is scant, with most studies finding either no, quantitatively small, or even ambiguous effects. More compelling is the evidence on source country policies, with studies finding that a key determinant of capital flows to EMEs - and especially of inflow surges - is advanced-economy interest rates. There is also evidence that pervasive capital account regulations may help to sustain undervalued exchange rates over long periods of time, which raises a range of multilateral issues.

Do the possible spillovers from capital account policies give rise to a need for multilateral coordination on the use of such policies? When capital controls are used to frustrate the 
external adjustment process, the answer is plainly yes (in the same spirit that trade policies that give unfair competitive advantage are proscribed). What this means in practice is not always clear-cut to be sure-inflow controls that support an excessive external surplus are likely to raise red flags in most cases, but when there is a genuine learning-by-doing externality in the export sector that, as a practical matter, can only be internalized by an undervalued currency, the basis for controls may be sounder and of less multilateral concern. ${ }^{2}$

Beyond this, there are three implications. First, although capital controls may deflect inflows from one country to another, this does not mean that the first country should refrain from acting: rather, all countries that are concerned about excessive (or excessively risky) inflows should take appropriate measures to safeguard stability. Indeed, spillover-effects are natural parts of how the market system adjusts to capital controls, and do not necessarily indicate inefficiency. Second, however, if recipient-country policy responses do not take account of possible deflection and the response of other countries, the outcome of uncoordinated policies may be inefficient in the sense that countries may end up imposing controls that are excessively restrictive from their own point of view. Third, globally efficient outcomes may also require coordination between recipient and source countries, although such coordination is less obviously in the interest of source countries, and thus more difficult to bring about.

So, is multilateral coordination of country-level policies desirable? The foregoing discussion suggests that such coordination may be warranted to prevent controls being used to underpin beggar-thy neighbor external sector strategies or terms of trade manipulation, to avoid potentially costly "wars" across recipient countries, and to induce source countries to take into account the impact of their policies on the level and riskiness of outflows. It is important to recognize that coordination might not involve capital account regulations as such, but instead monetary and prudential policies that affect the level and riskiness of flows.

But designing coordination in practice is much more difficult than recognizing its desirability in theory. The appropriate choice of policy intervention - and its calibration - depends crucially on specific circumstances, and it is impossible to fully spell out the nature of desirable coordination or multilateral rules ex ante. As such, any rules are likely to be "soft" rather than "hard" and to involve the application of judgment. Nevertheless, when deploying tools available to manage the level and composition of flows, countries should be guided by multilateral principles to ensure that their policies are in line with the global interest.

What might this mean in practice? Monetary and prudential policies in source countries would need to give an appropriate weight to spillovers on global flows and the

\footnotetext{
${ }^{2}$ Countries have an obligation under the IMF's Articles of Agreement to avoid manipulating exchange rates or the international monetary system in order to prevent effective balance of payments adjustment or to gain unfair competitive advantage. The "learning-by-doing" externalities discussed in this note are not meant to cover exchange rate policies that would violate this obligation.
} 
macroeconomic and financial-stability risks facing recipient countries. Capital account regulations that deflect flows and amplify risks in other countries would similarly need to internalize their external effects. Multilateral coordination would seek to encourage the adoption of policies that partially internalize spillovers. Inflow controls might thus be used less intensively when there are generalized surges to multiple countries, and policies in surplus countries that restrict inflows might likewise be adjusted at the margin. Supervisory policies in source countries would take account of risks imposed on foreign countries by financial institutions in the source countries. Policies undertaken to gain unfair competitive advantage, with no prudential benefit or genuine learning-by-doing externality, would raise red flags, even if identification of such policies is difficult in practice.

This note is organized as follows. Section II delves into the pure theory of capital controls (further analytic results are available in Korinek, 2012). Section III surveys the relevant empirical literature. Section IV discusses implications of the theory. Section V concludes.

\section{The Pure Theory of Capital Controls}

Before introducing the (many) real world complications, it is useful to consider first a highly stylized setup in which departures from the neoclassical paradigm are introduced one at a time in order to identify spillovers, externalities, and welfare implications of policy interventions. Accordingly, we consider a world free of any distortions. Countries may be large (able to influence world interest rates) or price-takers in world capital markets.

The interventions contemplated in this note may influence the volume of capital flows or the interest rate at which parties transact, regardless of the purpose of the intervention. These include capital controls and also prudential regulations (the former discriminate on the basis of residency, while the latter do not). The measures may be either temporary (e.g., cyclicallyvarying) or of a more structural nature (for example, the closure of the capital account to certain types of flow). Less obviously, monetary and fiscal policies may also have significant effects on cross-border flows and, to the extent they do, are included in the discussion here.

\section{Terms of trade manipulation with market power}

In a world without distortions, would there be any reason to interfere with the free movement of capital across borders? The answer is yes, for the same reason that countries large enough to exert market power may want to impose export taxes or import tariffs. Specifically, creditors may benefit from restricting the supply of capital, driving up the world interest rate and shifting the terms of trade in their favor. ${ }^{3}$ For any individual creditor, the best outcome is one in which other creditors restrict their supply so that he can benefit from the better terms

\footnotetext{
${ }^{3}$ In contrast to the optimal tariff argument for goods trade, here creditors suffer a capital loss (depending on the duration of assets) but gain in flow terms when interest rates rise. In what follows, we ignore the first effect.
} 
of trade on the same - or an even higher-volume of flows. By the same token, debtors benefit from restricting the demand for capital, thereby improving their terms of trade.

While a theoretical possibility, it may seem far-fetched to view large creditors or debtors as deliberately seeking to reduce supply or demand for capital in order to manipulate the world interest rate. But if one considers a broader array of policy interventions (rather than, say, just capital controls) that could influence the volume or price of capital flows (for example, monetary policy), the argument may have an aura of plausibility. To the degree that it does, the case parallels that of the goods market monopolist/monopsonist. Moreover, if both creditors and debtors try to manipulate the terms of trade, then neither succeeds, the world interest rate remains the same, and both lose by the lower volume of cross-border asset trade.

\section{Capital controls to address domestic distortions}

Leaving aside incentives for non-competitive behavior, the modern theory of capital controls stresses distortions in the domestic economy that result in excessive foreign borrowing as a rationale for imposing capital controls that can reduce the volume of risky inflows. The externalities may be various. The most obvious are financial-stability risks (Korinek, 2011). In particular, individual domestic borrowers may fail to take account of the externality of their borrowing on the economy's collateral constraint, which binds in the event of a crisis. As a result, the competitive equilibrium entails excessive - and excessively risky (short-term, FX-denominated) - foreign borrowing. The national welfare perspective may therefore call for some form of tax on foreign borrowing, particularly on the more risky instruments.

While distortions emanating from the financial sector are an obvious example where foreign inflows might exacerbate existing externalities, it is not the only example. Another possibility is learning-by-doing externalities in the production of exportables. A country with such an externality might engage in sterilized FX intervention to achieve an undervalued currency, and inflow controls might be essential to maintain the exchange rate at the right level given the production externality (however, this would not be the first-best response, which would be a production subsidy, see Box 1). The capital inflow controls would increase the current account surplus and reduce capital inflows; it is easy to see, moreover, that there exists a "reserve-accumulation-equivalent" to the capital control, as shown in Box 2.

\section{Multilateral implications of inflow controls}

What would be the ramifications of such a policy intervention? Begin with the case where there are no distortions in any other country. The capital control (or other policy intervention) by the borrower with the domestic distortion reduces inflows to that country (or increases its current account surplus), thereby reducing world demand for capital and depressing world interest rates (by how much depends on the size of the country in world capital markets). Borrowers gain and creditors lose. But this is just a pecuniary externality, inherent to free markets and, from a global perspective, economically efficient (Box 3). 


\section{Box 1. Learning-By-Doing Externalities in Exportable Production}

We consider a two-period, traded/non-traded good economy that can borrow or lend internationally at a rate $(1+r)$. An externality in the production of traded goods means that a higher level of production, perhaps because of learning-by-doing, leads to greater productivity in the tradable goods sector in the future. With labor the only factor of production, output in the traded goods sector is given by: $y_{1}^{T}=f\left(l_{1}\right)$; and $y_{2}^{T}=A\left(y_{1}^{T}\right) f\left(l_{2}\right)$ where $f^{\prime}(\cdot)>0, f^{\prime \prime}(\cdot)<0$ is a standard neoclassical production function and the productivity parameter $A$ obeys $A \geq 1 ; A^{\prime}(\cdot)>0$. Output in the non-traded goods sector is not subject to the production externality: $y_{1}^{N}=g\left(1-l_{1}\right) ; y_{2}^{N}=g\left(1-l_{2}\right) ; g^{\prime}>0, g^{\prime \prime}<0$.

Decentralized Economy, Planner's Optimum, and Optimal Government Intervention

Since the learning-by-doing is external to (i.e., cannot be captured by) the firm, the competitive equilibrium entails too little production of the traded good. Specifically, in the first period, the competitive equilibrium sets the marginal rate of transformation between traded and non-traded goods equal to the real exchange rate (the relative price of non-traded goods) taking as given the externality:

$$
f^{\prime}\left(l_{1}\right) / g^{\prime}\left(1-l_{1}\right)=p_{1}
$$

whereas the national social planner, who takes account of the positive externality, would allocate a larger share of the labor force to the production of traded goods:

$$
\left[1+A^{\prime}\left(y_{1}^{T^{*}}\right) f\left(l_{2}^{*}\right) /(1+r)\right] f^{\prime}\left(l_{1}^{*}\right) / g^{\prime}\left(1-l_{1}^{*}\right)=p_{1}
$$

The government can reproduce the national social planner's optimum by offering a subsidy that encourages the production of traded-goods, where the optimal subsidy would be:

$$
s^{*}=A^{\prime}\left(y_{1}^{T^{*}}\right) f\left(l_{2}^{*}\right) /(1+r)>0
$$

Since this subsidy reproduces the national social planner's equilibrium, it is the optimal intervention; in particular, producers face the more depreciated real exchange rate (given by $p_{1}^{*} / s^{*}$ ) while consumers face $p_{1}$.

\section{Capital Controls}

Although a production subsidy to the traded goods sector is the optimal intervention, it requires budgetary sources to implement, and a tax on nontraded production could be difficult to implement if that sector is largely informal. Ghosh and Kim (2008) consider several alternative strategies (export subsidy/import tariff; consumption tax; undervaluation), none of which is first best because they distort the producer and consumer's decision, resulting in too large a current account surplus. Of relevance here is the strategy to impose a control on capital inflows and support an "undervalued" exchange rate through sterilized intervention. The intervention absorbs an amount $\mathrm{R}$ of inflows. If $i$ is the domestic interest rate at which households and firms transact, and $r$ is the world interest rate, then the cost of sterilized intervention in an amount $R$ entails a fiscal cost of $(i-r) R$.

This is why the strategy needs some limit on the amount of inflows (such as capital controls), otherwise the sterilization cost would be infinite. To see that controls-cum-intervention can be welfare enhancing, it suffices to note that the representative citizen's indirect utility is increasing in $\mathrm{R}$ when starting at $\mathrm{R}=0$ :

$$
U^{\prime}(R)=\left[\beta(1+r) u_{2}^{\prime}-u_{1}^{\prime}\right]+\beta u_{2}^{\prime} A^{\prime}\left(y_{1}^{T}\right) f\left(l_{2}\right) \partial y_{1}^{T} /\left.\partial R \Rightarrow U^{\prime}(R)\right|_{R=0}>0
$$

At $\mathrm{R}=0, i=r$, so the consumer's usual Euler equation ensures that the first term of (4) is zero at $\mathrm{R}=0$, while the second term is necessarily positive because the intervention serves to depreciate the real exchange rate, encouraging a re-allocation of labor to the traded goods sector. Although this strategy can achieve the appropriate level of tradables production, it is not the optimal intervention because it also distorts the consumption decision, implying excessive saving and therefore an excessive current account surplus.

More generally, whether the policy involves exchange rate undervaluation or a production subsidy, there are the usual risks of policy intervention - namely that the externality does not really exist but exporters successfully lobby for the intervention, which is socially welfare-reducing, or that the "infant industry" never grows up. From the perspective of other countries, currency undervaluation is worse than a production subsidy because it tends to vitiate their own attempts to promote tradables production through undervaluation. For creditor countries (i.e., the source of capital flows), currency undervaluation may also be worse because it leads to a larger reduction in the recipient country's current account deficit, thus shifting the intertemporal terms of trade against creditors. 


\section{Box 2. Equivalence of Capital Controls and Reserve Accumulation}

To what extent is use of capital controls equivalent to sterilized foreign exchange intervention? Capital controls reduce the country's net demand for foreign funds and the world interest rate. Likewise, intervention that prevents currency appreciation leads to a larger current account surplus and downward pressure on world interest rates. Take the case of a region that constitutes a fraction $m^{i}$ of the world economy and that marginally increases its capital control. Applying the implicit function theorem to the equation (1) in Box 2, higher capital controls raise the region's net foreign asset holdings by:

$$
b_{\tau}^{i}=\frac{u_{c}\left(c_{1}\right)}{-\left(1-\tau^{i}\right) u_{c c}\left(c_{1}\right) / R-\beta R u_{c c}\left(c_{2}\right)} \approx c^{i} / 2 \sigma>0
$$

The approximation assumes that capital controls, the net interest rate and the discount rate are sufficiently close to zero and that period 1 and 2 consumption are close to each other. Calibrating the coefficient of relative risk aversion $\sigma$ to the standard value of 2 implies that a one percentage point increase in capital controls leads to a reduction in capital inflows/GDP (or increase in outflows) of 0.25 percentage points. Or, flipping this around, reserve accumulation of 1 percent of GDP is equivalent (in terms of the impact on the global capital markets) to imposing a 4 percent capital control.

The world excess demand for bond holdings is the weighted sum of all bond positions over all regions, $B=\Sigma m^{i} b^{i}$. Using the same approximations as above, its response to a change in the world interest rate is

$$
B_{R}=\frac{\partial \Sigma m^{i} b^{i}}{\partial R}=-\Sigma_{i} m^{i} \frac{\left(1-\tau^{i}\right) u_{c c}\left(c_{1}^{i}\right) b^{i} / R^{2}-\beta u_{c}\left(c_{2}^{i}\right)}{-\left(1-\tau^{i}\right) u_{c}\left(c_{1}^{i}\right) b^{i} / R-\beta R u_{c c}\left(c_{2}^{i}\right)} \approx y / 2 \sigma>0
$$

where $y$ is global GDP. Combining (1) and (2), the effect of capital controls in one region $i$ on the world interest rate is given by the weighted share of region $i$ 's consumption in world GDP:

$$
R_{\tau}^{i}=\frac{\partial R}{\partial \tau^{i}}=\frac{-m^{i} b_{\tau}^{i}}{B_{R}} \approx-m^{i} c^{i} / y
$$

For example, if a country like Brazil, which produces about 3.3 percent of world GDP, imposes an inflow tax of 1 percent, it reduces the world interest rate by 0.033 percentage points. If a country such as China that produces about 10 percent of world GDP accumulates 1 percent of GDP in foreign reserves or, equivalently, imposes a 4 percentage point capital control, then it pushes down the world interest rate by approximately 0.4 percentage points. In practice, of course, the use of capital controls and reserve accumulation are not necessarily substitutes: capital controls are often used to support a policy of sterilized intervention.

Now suppose, more realistically, that other borrowers likewise face distortions in the form of excessive foreign borrowing. Imposition of capital controls by one country lowers world interest rates and deflects capital, exacerbating other borrowers' inflow problem. But this is not a reason for the country to refrain from acting, because spillovers here are pecuniary externalities. The efficient outcome is rather for all (excessive) borrowers to act. This will imply lower world interest rates, benefiting borrowers and hurting creditors without harming global efficiency (Box 3). The same logic applies to a learning-by-doing production externality as to the financial-stability externality. While action by one country makes it more difficult for others to internalize their externalities (not everyone can run larger surpluses ${ }^{4}$ ), from an efficiency standpoint, the resulting pecuniary externalities are globally efficient.

\footnotetext{
${ }^{4}$ If exportables are differentiated products, then all countries can export more. If the learning-by-doing stems from exportables production, then all countries can reap the benefits of a production subsidy. But since not all countries can run larger external surpluses, the controls-cum-undervaluation strategy (which, unilaterally, leads to excessive saving and current account surplus) becomes both unilaterally and multilaterally inefficient.
} 


\section{Box 3. Global Efficiency of Correcting Domestic Externalities}

Can capital controls - such as taxes on inflows - help address domestic externalities? And would this be globally efficient? Box 1 considered the specific example of a learning-by-doing externality. This box generalizes the result and discusses whether such policy interventions are globally efficient. Again we consider a two-period, open economy model, where the utility function of the representative agent in country $i$ is:

$$
U^{i}=u\left(c_{1}^{i}\right)+\beta u\left(c_{2}^{i}\right)
$$

The agent's budget constraints imply $c_{1}^{i}=y_{1}^{i}-\left(1-\tau^{i}\right) b^{i} / R+T^{i}$ and $c_{2}^{i}=y_{2}^{i}+b^{i}$ where $c$ is consumption, $y$ is output, $b$ is foreign bonds (negative if the country is a debtor), $\tau$ is the capital control (a tax on foreign borrowing, a subsidy on foreign lending), $\mathrm{R}$ is the world interest rate, and $\mathrm{T}$ the lump-sum rebate of the capital control revenues. The first-order condition characterizing the representative agent's optimal consumption and foreign borrowing (or lending) decision equates the marginal rate of substitution to the after-tax rate of return:

$$
\left(1-\tau^{i}\right) u_{c}\left(c_{1}^{i}\right)=\beta R u_{c}\left(c_{2}^{i}\right)
$$

Now suppose that there is a negative externality associated with foreign borrowing. Korinek (2012) considers externalities in the financial sector such that atomistic domestic agents, who fail to take account of the externality, engage in excessive (or excessively risky) foreign borrowing; Ghosh and Kim (2008), Rodrik (2008), and Box 1 above consider a learning-by-doing production externality in the tradable goods sector.

Regardless of the specific nature of the externality, it can be written (in utility-equivalent terms) as $\xi^{i} b^{i}$ so that the representative agent's true welfare function is $W^{i}=u\left(c_{1}^{i}\right)+\beta u\left(c_{2}^{i}\right)+\xi^{i} b^{i}$ (though the agent ignores the externality when choosing his optimal consumption and borrowing). The national social planner does take account of the externality, yielding the first-order condition:

$$
u_{c}\left(c_{1}^{i}\right)=\beta R u_{c}\left(c_{2}^{i}\right)+\xi^{i} R
$$

Comparing (2) and (3), the government can reproduce the national social planner's optimum by imposing a tax on capital flows equal to

$$
\tau^{i}=\xi^{i} R / u_{c}\left(c_{1}^{i}\right)
$$

thus forcing the representative agent to take account of the negative externality (e.g., on financial stability) associated with his foreign borrowing. In a multi-country world, where there are $N$ (not necessarily identical) countries, the world interest rate, R, will adjust to ensure that the capital market clears: $\sum_{j=1}^{N} b^{j}=0$.

The tax on foreign borrowing is optimal from the individual country's perspective. But is it globally efficient? It turns out that it is. This can be shown by considering the optimal allocation that would be chosen by a global social planner who optimizes a weighted sum of national welfares, assigning to country $i$ a weight $\phi^{i}$, subject to each country's budget constraint and the global market clearing condition $\Sigma_{j=1}^{N} b^{j}=0$, which has a shadow price (Lagrange multiplier), $v$. The first-order condition characterizing the global social planner's optimum is:

$$
u_{c}\left(c_{1}^{i}\right)=\beta R u_{c}\left(c_{2}^{i}\right)+\xi^{i} R+v R / \phi^{i} i=1, \ldots N
$$

At the global social planner's optimum, $v=0$, because the planner does not need any additional bonds to achieve the optimal allocation (so the shadow value on easing the constraint on the global supply of bonds is zero). Setting $v=0$ in (5) and comparing to (3) shows that the national social planners (whose optimal decisions are given in (3)) achieve the same allocation as the global social planner (whose optimal allocation is given in (5)). The intuition for why the Nash equilibrium among national planners is globally efficient is simple: each planner has one target (i.e., to offset the externality) and one instrument (the tax on capital flows) - a general result in the theory of policy coordination is that when countries have as many instruments as targets, there is no need for coordination as the Nash equilibrium will be efficient (see Ghosh and Masson, 1994). 


\section{Costly capital controls}

The notion that all borrowers that are borrowing excessively should impose capital controls implicitly assumes that such controls are costless. In practice, there are likely to be several types of cost associated with such policies: administrative cost (i.e., paying officials to administer the controls); compliance costs for financial institutions and others affected by the controls; and efficiency costs due to imperfect targeting of excessively-risky forms of inflow. There are also costs from implementing an export-led growth strategy supported by inflow controls (as an answer to a production externality), most notably quasi-fiscal sterilization costs and distortive effects on consumption (controls lead to excess saving). Finally, since imposition of controls may create vested interests, these costs may be long lasting.

While administrative and compliance costs should not be downplayed, it is the economic distortions - collateral damage - caused by imperfect targeting of risky flows that is likely to be especially important. It stands to reason, moreover, that the more intensive the control, the greater the collateral damage. For instance, since a higher tax rate will give greater incentive for circumvention, its breadth of application will rise, and caught in the net will be flows that otherwise would not merit being restricted. As such, the cost function is likely to be convex: not only increasing in the intensity of the control, but increasing at an increasing rate.

Costliness of controls implies that actions by other borrowers or creditors that exacerbate domestic distortions (e.g., by lowering world interest rates and inducing more inflows where there is already over-borrowing) have substantial multilateral welfare implications. Costly spillovers existed above, but they were immaterial because (by assumption) they could be costlessly offset by countries. Even when offsetting policies are not costless, there is no presumption that actions to offset domestic externalities should be proscribed. But it is likely that in such cases, unfettered unilateral actions will no longer be globally efficient (Box 4). ${ }^{5}$

This is perhaps very stark in the case of multiple countries attempting to pursue an export-led growth strategy. Since it is not possible for all countries to run larger surpluses, the futility of unilateral policies is readily apparent. Moreover, the benefit-cost calculus for a capital controls war that stifles goods trade is likely to be much less favorable than when the war is based on deflecting capital flows. The reason is that, in the extreme, when international asset trade falls to zero because of prohibitive capital controls, the resulting stifling of asset trade also means that financial-stability risks from cross border flows (the externality) fall to zero. But when goods trade falls to zero, the resulting stifling of goods trade means not only that gains from trade are extinguished, but also that none of the production externality is captured.

\footnotetext{
${ }^{5}$ Specifically, regardless of whether costs are linear or convex, there will be a case for coordination among capital-receiving countries. If costs of controls are convex, global efficiency will also necessitate coordination between borrowers and lenders, so that the marginal cost of inflow controls in the recipient country equals the marginal cost of outflow controls in the source country. If costs are instead linear, then the global efficiency criterion does not, itself, determine the optimal split between inflow and outflow controls.
} 


\section{Box 4. Role for Coordination under Costly Capital Controls}

As discussed in Box 2, when there are domestic externalities associated with capital flows, governments can induce domestic agents to take account of them by imposing taxes on the flows. Moreover, these (uncoordinated) taxes are globally efficient. But are there circumstances under which they would not be efficient and coordination would be required? The answer is yes, provided the capital controls themselves entail costs. Again we consider a two-period model where the representative agent disregards the externality associated with capital flows. The national planner must choose the optimal tax on capital flows to maximize welfare taking account of the welfare cost of imposing capital controls, given by $\Omega(\tau)$, where the cost function is assumed to be increasing and convex (increasing at an increasing rate) in the tax rate: $\Omega^{\prime} \geq 0, \Omega^{\prime \prime}>0$ :

$$
W^{i}=u\left(c_{1}^{i}\right)+\beta u\left(c_{2}^{i}\right)+\xi^{i} b^{i}-\Omega\left(\tau^{i}\right)
$$

The resulting first-order condition characterizing the national social planner's optimum is:

$$
u_{c}\left(c_{1}^{i}\right)=\beta R u_{c}\left(c_{2}^{i}\right)+\xi^{i} R-\Omega^{\prime}\left(\tau^{i}\right)\left(1-\tau^{i}\right)\left(\sigma_{1}^{i}+R \sigma_{2}^{i}\right)
$$

where $\sigma_{t}^{i} \equiv u_{c c}\left(c_{t}\right) / u_{c}\left(c_{t}\right), t=1,2$. The terms in (2) trade off the benefits of foreign flows for consumptionsmoothing against the domestic externality but also the cost of imposing capital controls. Solving for the national planner's optimal tax rate shows that it will be positive as long as there is an externality, but it will fall short of fully offsetting the externality because of the costs associated with the imposition of the control:

$$
0 \leq \tau^{i}<\xi^{i} R / u_{c}\left(c_{1}\right)
$$

By contrast, when controls are not costly, the planner fully offsets the externality (see eqn. (4) in Box 2). What tax rates would a global planner choose for each country, $i=1, . . N$ ? It can be shown that they must satisfy:

$$
\sum_{j=1}^{N}\left(1-\tau^{j}\right) \Omega^{\prime}\left(\tau^{j}\right)=0
$$

that is, the global social planner will try to minimize the aggregate global cost of the capital controls by spreading the use of controls across countries (given the convexity of the capital control cost function, it is better to have two countries impose relatively low controls than to have one country impose high controls). More precisely, the weighted average marginal distortion imposed by capital controls must be zero as in (4).

If there are no externalities associated with capital flows $\left(\xi^{i}=0 \forall i\right)$, then the solution to (4) is simply $\tau^{i}=0 \forall i$ - the global planner sets all tax rates equal to zero. This is intuitive, and is the only case where the nationally chosen tax rates (3) coincide with those chosen by the global planner (4). More generally, (3) and (4) will differ, and the uncoordinated equilibrium among national planners will be globally inefficient (intuitively, each planner now has two targets - offsetting the domestic distortion and minimizing capital control costs - but still only one instrument, so the uncoordinated equilibrium is inefficient). Consider the following examples and some for the calibration exercises in Box 5:

Example 1 (Symmetric countries). Consider a world economy of $k \geq 1$ identical countries that impose capital controls to offset domestic externalities, incurring a cost $\Omega\left(\tau^{i}\right)>0$. Since countries are identical, however, the capital controls simply deflect capital to each other, with no net effect on flows or the externality. Therefore, it is Pareto efficient to set all controls to zero, thus avoiding the cost of controls. Indeed, that is the global social planner's solution (the only solution to equation (4) for symmetric countries is $\Omega\left(\tau^{i}\right)=0 \forall i \Rightarrow \tau^{i}=0 \forall i$ ).

Example 2 (Two countries with asymmetric externality). Consider a world with countries $i$ (borrower) and $j$ (lender). Country $i$ experiences an externality from excessive inflows $\xi^{i}>0$, so its planner imposes an inflow control, $\tau^{i}>0$ whereas country $j$ will not impose any controls. This equilibrium is inefficient and the optimality condition (4) is violated. A global planner would lower the tax rate in country $i$ and impose a tax on outflows in country $j$. Given the convexity of costs, the sum of the deadweight loss from the (lower) inflow control plus the outflow control will be less than the cost of a high inflow control in the borrowing country. 


\section{Box 5. Gains from Coordination under Costly Capital Controls}

This Box provides a simple calibration of the gains from coordination under costly capital controls. We focus on capital flows between two regions - a borrowing region that exhibits domestic externalities and a lending region that is not subject to externalities. The relative size of the two regions is assumed to be three-to-one, roughly corresponding, for example, to the relative sizes of the US and Latin America. In our example, reported in the first panel of Table 1, the borrowing region imports capital in the amount of 3.1 percent of GDP at a world interest rate of 4.1 percent in the laissez faire equilibrium.

We assume that the externality $\xi^{i}$ in the borrowing region is 6 percent, and that both regions experience a resource cost of imposing capital controls that takes the functional form $\Omega(\tau)=\alpha \tau^{2}$. The parameter $\alpha$ is set to 0.05 so that planners in the borrowing region find it optimal to correct only two-thirds of the externality in the absence of coordination, imposing a 4 percent inflow tax. Since there are no externalities among lenders, domestic planners in that region impose no controls on lending. In the resulting equilibrium, reported in the second panel of Table 1, capital flows in the borrowing region decline to 2.3 percent of GDP, corresponding for example to the situation in Brazil in 2010. The world interest rate falls to 3.1 percent per year due to the lower worldwide demand for capital. In the Nash equilibrium among planners, capital controls increase the welfare of borrowers by the equivalent of a 0.048 percent increase in consumption and reduce the welfare of lenders by .009 percent due to the lower interest rate. (If borrowers compensated lenders for their loss, they would still enjoy a welfare gain of 0.020 percent.)

Table 1. General Equilibrium Effects of Capital Controls with and without Coordination

\begin{tabular}{l|cc|cc|cc|cc} 
& \multicolumn{2}{|c|}{ Laissez Faire } & \multicolumn{2}{|c|}{ Nash Equilibrium } & \multicolumn{2}{c|}{ Full Coordination } & \multicolumn{2}{c}{$\begin{array}{c}\text { Coordination with } \\
\text { Restricted Lender }\end{array}$} \\
\cline { 2 - 9 }$\xi=6 \%$ & Borrower & Lender & Borrower & Lender & Borrower & Lender & Borrower & Lender \\
\hline capital control & $0 \%$ & $0 \%$ & $4.04 \%$ & $0 \%$ & $3.13 \%$ & $-0.90 \%$ & $3.72 \%$ & set to 0 \\
CA/GDP & $-3.09 \%$ & $1.03 \%$ & $-2.32 \%$ & $0.77 \%$ & $-2.33 \%$ & $0.78 \%$ & $-2.38 \%$ & $0.79 \%$ \\
interest rate & $4.12 \%$ & & $3.09 \%$ & & $4.03 \%$ & & $3.17 \%$ & \\
$\Delta$ welfare LF & 0 & 0 & $0.0479 \%$ & $-.0088 \%$ & $0.0496 \%$ & $-.0088 \%$ & $0.0481 \%$ & $-.0088 \%$ \\
wwelfare Nash & & & 0 & 0 & $0.0017 \%$ & 0 & $0.0002 \%$ & 0
\end{tabular}

If all countries in the two regions coordinate their use of capital controls, a more efficient global equilibrium can be achieved. As reported in the third panel of Table 1, the borrowing region reduces its inflow tax from 4 percent to 3.1 percent and the lending region imposes a control of 0.9 percent on outflows. The sum of the two controls is almost unchanged from the Nash equilibrium, but since the cost of imposing capital controls is convex, the two regions reduce the aggregate cost $\Omega(\tau)$ by sharing the burden of regulation.

The net global welfare gain from coordination is equivalent to a .0017 percent increase in consumption of the borrowing country. Observe that this gain is an order of magnitude lower than the gains of going from laissez faire to the uncoordinated Nash equilibrium among national planners. (For ease of interpretation, we assume that in coordinated equilibria, a transfer from lenders to borrowers keeps the welfare of lenders unchanged from the Nash equilibrium.)

Finally, we consider a global planner who internalizes the general equilibrium effects of capital controls on the world interest rate but cannot impose capital controls in the lending region. This situation may reflect for example that this region is an important financial center where the imposition of capital controls would carry prohibitive costs. The resulting equilibrium is reported in the last two panels of Table 1. All countries in the borrowing region now impose capital controls that are smaller than the unilaterally optimal controls in the Nash equilibrium, but larger than in the case of full coordination.

As a result, the world interest rate and welfare marginally increase compared to the Nash equilibrium, but the gains are smaller than in the case of coordination with lenders. The global planner reduces the capital control for borrowers even if lenders cannot adjust their controls because he recognizes that lowering borrowers' controls raises the world interest rate, which also discourages borrowing but without imposing the deadweight loss $\Omega(\tau)$. (For this form of coordination to lead to a Pareto improvement, the global planner again needs to compensate borrowers for the higher interest burden by making a compensatory transfer from lenders.) 


\section{Coordination among borrowers}

Coordination between borrowing countries imposing controls on capital inflows is necessary because, if they fail to coordinate, each country may end up imposing controls that are too high from its own perspective. This result actually follows directly from the country's costbenefit calculus in choosing the level of capital controls given its distortive cost. When the country ignores the repercussions on other borrowers of the deflected capital flows and their likely reaction to them, it overestimates the benefit of the controls because it fails to recognize that the equilibrium reduction in inflows will be smaller once other countries react by imposing their own controls. Put differently, at the end of the capital control war, borrowing countries would find that, from their own perspectives, capital controls are too high (and the volume of flows too low): each borrower that imposed controls would be better off if they could jointly agree to lower controls from their uncoordinated equilibrium levels.

\section{Source-country policies}

The second inefficiency concerns the role of creditor countries in managing outflows. If the cost of capital controls is convex, then it would be more globally efficient to split that cost between borrowing countries (who would impose controls on inflows) and lending countries (who would impose controls on outflows). ${ }^{6}$ One obstacle to such coordination is that capitalexporting countries do not directly benefit from moving from the uncoordinated equilibrium (where they do not impose controls or adjust other policies-e.g., monetary policy—to take account of the impact on borrowing countries, and therefore do not incur any associated costs) to the coordinated equilibrium (where they incur such costs).

Nevertheless, it may be in the interests of capital-sending countries to impose some restraint on outflows, especially when these are exacerbating global financial-stability risks. First, they may simply want to contribute to global stability, recognizing that it is a public good. Second, inasmuch as crises in recipient countries imply losses for financial institutions in source countries, it may be in the latter's interest to reduce the risk of such crises. ${ }^{7}$ In that case, measures that reduce the volume or riskiness of outflows constitute a form of prudential regulation for banks in creditor countries. Third, creditor countries enjoy a terms of trade

\footnotetext{
${ }^{6}$ Coase's (1960) theorem on the irrelevance of the assignment of externality-generating rights does not apply here because convex costs imply that technological efficiency requires splitting the burden of capital controls between source and recipient countries.

${ }^{7}$ A voluminous literature documents the impact on source countries of financial crises in borrowing countries: see, e.g., Sachs and Huizinga (1987) on the Latin America debt crisis (which posed a systemic threat to U.S. banks); and Boughton (2012) for discussion of the Asia and Russian crises. If source countries have their own incentive to restrict outflows (perhaps because of negative repercussions of a crisis in the borrowing country), then global efficiency requires the equalization of the marginal cost of inflow controls in the recipient country to the marginal cost of outflow controls in the source country; when these costs are linear (i.e., not convex), the global efficiency criterion does not pin down the optimal split between inflow and outflow controls.
} 
gain on their flow of lending by reducing the supply of capital, so measures that reduce outflows would be in their interest — even if undertaken in order to reduce financial-stability risks in recipient countries. In this case, there is a happy coincidence whereby the (incidental) exercise of monopoly power by source countries helps debtor countries which would otherwise be over-borrowing.

In sum, once we depart from the first-best world of perfect markets there may be valid economic reasons for interventions to address domestic externalities such as those that result in excessive — or excessively risky - foreign borrowing. And, as a matter of logic, in a second best world, policy actions by borrowers or lenders can exacerbate existing externalities such that cross-border spillovers have global welfare implications. In general, this does not mean that countries should refrain from policy interventions - but it does mean that efficient outcomes will likely require coordinated policies. This is a fortiriori the case when capital controls are being pursued to support an export-led growth strategy. When naked mercantilism is the basis of policy at the country level, it is clear that the policy is neither unilaterally nor multilaterally efficient. But even when such policy is unilaterally desirable, say because of genuine learning-by-doing externalities in exportables production, the need for multilateral coordination to avoid self-defeating policies is very clear. ${ }^{8}$

\section{SURVEY OF EMPIRICS}

Any call for policy coordination - both among capital-recipient countries, and between capital-exporting and capital-importing countries - is predicated on the relevant spillovers being quantitatively important. Indeed, if capital controls (and other policies that have similar effects) do not have a significant impact even on the flows to the country imposing them, then the whole discussion is moot. In this section, therefore, we review existing evidence on three questions: do capital controls alter the volume or composition of capital inflows? Does the imposition of controls by one borrower deflect flows to others? And do policies in source countries appreciably affect the volume of cross border flows to capital-recipient countries?

\section{Volume and composition of capital inflows}

Most of the evidence on the effectiveness of capital controls suggests that they have little effect on overall flows. This finding relates to countries that have relatively open capital accounts (many of today's emerging market countries, for example); there is little doubt that countries that are less well integrated in global capital markets can influence the magnitude of flows through a range of administrative measures and quantitative limits. In general, the effectiveness of controls in regulating the magnitude of flows depends on how extensive they

\footnotetext{
${ }^{8}$ Moreover, learning-by-doing externalities seem more relevant for countries behind the technological frontier, not for those at the frontier. So the basis of an undervaluation strategy is likely to be fundamentally asymmetric.
} 
are, whether the country maintains the necessary administrative and institutional infrastructure to enforce controls, and the extent of investors' incentives to circumvent them.

The lack of convincing evidence on the impact of controls on the overall level of capital flows likely reflects a number of factors. For countries with relatively open capital accounts, capital controls have represented marginal changes that have been undertaken alongside a range of other measures which also impact flows, increasing the difficulty of isolating the effects of capital control measures themselves. Measuring the intensity of capital controls has also been a problem plaguing empirical investigations. And perhaps foremost are fundamental econometric identification problems - if countries that are facing large inflows are the ones that impose controls, it is not surprising that econometric studies find no, or even a positive, relationship between controls and the magnitude of inflows.

In light of these identification problems, the existing empirical studies should not lead one to conclude that controls have no traction in managing the level of flows. The empirical evidence that controls have a systematic impact in tilting the composition of flows, moreover, also casts doubt on the notion that the aggregate volume of flows is impervious to the level of controls. This is because, if there are no aggregate volume effects but significant compositional effects, there would need to be full offsets across different types of flow in response to controls. This seems highly implausible, given the different forces that likely drive the individual components of the capital account. If, for example, controls help to curtail inflows of short-term debt, it is much more likely that total inflows would be reduced than that another component of the capital account - e.g., foreign direct investment - would rise dollar-for-dollar with the reduction in short-term debt.

We conclude that the lack of strong evidence in favor of aggregate effects of capital controls reflects more the difficulties of getting the data to speak loudly than a lack of traction of the policies themselves. Literature reviews and meta-studies (including Magud et al. (2011), Habermeier et al. (2011) and Ostry et al. (2010, 2011)) suggest that capital account policies have traction along a number of dimensions - monetary policy independence, the exchange rate path, and compositional effects. While evidence of an impact on the total volume of flows is thus hard to come by, this may reflect identification problems more than reality.

\section{Diversion and cross-border spillovers}

If capital controls impact the aggregate level of flows, there is obviously potential for them to have welfare implications for other countries, e.g., by diverting flows in situations where such diversion would amplify existing distortions. Is there any evidence to confirm this notion? Direct evidence of cross-border effects from capital account policies is mixed, an unsurprising finding in the light of the limited evidence that such policies have sizable effects on capital flows to the country imposing the measure. Forbes et al. (2011) finds small average effects on flows to other countries from the imposition of capital controls by Brazil: some countries saw increases in inflows as a result of the Brazilian measures, while others 
saw decreases. IMF (2011) using a slightly different methodology/data comes to a similar conclusion, that capital account policies have on occasion led to increases or decreases in flows to other countries. Both studies suggest different explanations to rationalize the results, including search for yield (which pushes capital to countries with no controls) or amplified risks of the imposition of controls in other countries (deflecting capital toward countries deemed less likely to impose controls), which may lead total outflows from source countries to diminish. The latter result - that capital is deflected away from other countries likely to impose controls - means that a capital control war between capital-receiving countries is unlikely to occur. Inasmuch as countries that are facing excessive inflows are more likely to want to impose controls, it may also mean that the deflection is efficient.

\section{Source-country policies}

What are the effects of source country policies on capital flows to emerging economies? There is certainly plenty of evidence along a broader dimension of this question, for example, the spillover effects from monetary policy in source countries through cross-border flows (e.g., Calvo et al., 1993; Taylor and Sarno, 1997; Reinhart and Reinhart, 2008; Ghosh et al., 2012). Indeed, empirical studies typically find that advanced economy interest rates (or other proxies for monetary policy) are among the most important determinants of capital flows to EMEs. ${ }^{9}$ The existence of spillovers from a range of policies (monetary, financial, fiscal, regulatory, and structural) has been documented in the series of spillover reports undertaken by the Fund over the past year: such spillovers can and do operate in part through crossborder financial flows and can have welfare implications when the resulting flows exacerbate pre-existing distortions. Spillovers from macroprudential policies are also evident in cases where, for example, deficiencies in domestic prudential or regulatory policies amplify the extent of risky cross-border capital flows (IMF, 2011).

To sum up, empirical evidence on the impact of capital account policies is mixed, and generally stronger in terms of finding an effect on the composition of flows than on the aggregate level. However, the finding of negligible effects on aggregate flows may reflect econometric identification problems more than reality. Similarly, the finding of small crossborder spillovers may reflect more the small measured unilateral effects than a true absence of spillovers (and possibly also the fact that measures imposed to date have been small in the grand scheme of things). The potential for spillover effects from capital account policies, moreover, would seem to be a salient risk were capital controls to become larger in the future. Whatever stand one takes on the strength of the empirical evidence, the logical arguments presented in Section II, and their implications presented in Section IV below, will remain valid. If the spillovers and distortions are strong, then the case for multilateral

\footnotetext{
${ }^{9}$ Note that the argument, sometimes made, that quantitative easing produces a wall of liquidity that washes over emerging market countries, should really be recast in terms of the prices of different assets, with the actions by central banks engaged in $\mathrm{QE}$ providing incentives to invest in riskier assets, including riskier foreign assets.
} 
coordination of individual actions is correspondingly strong; if the spillovers and distortions are weaker, the case for coordination is still there, but less essential.

\section{IMPLICATIONS}

The discussion in Section II points to the potential benefits of greater coordination among capital-receiving countries, between source and recipient countries when the latter are being swamped by inflows that threaten financial-stability, and across the international community more broadly when controls have the effect of vitiating external adjustment. While empirical evidence on the extent of spillovers is mixed, the potential for spillovers - especially if controls were to proliferate - is certainly there; and evidence of spillovers from sourcecountry policies on capital flows is well-documented. These considerations suggest that global welfare may be enhanced by some multilateral coordination of country policies with the goal of internalizing spillovers from macro-economic, prudential, and capital control measures. Multilateral institutions such as the IMF could provide a forum for identifying the spillovers and encouraging countries to internalize these external effects. We draw four implications from our analysis, leaving to others the development and subsequent operationalization of actual "rules of the road," which need to reflect a host of factors other than those considered in the previous sections. Indeed, Fund staff are in the process of crystallizing their views with the intention of proposing an institutional position on these issues, and the present paper in no way prejudges the outcome of this ongoing process.

\section{Implication 1: Capital controls and related measures (including prudential, monetary and fiscal policies as relevant) should not substitute for warranted external adjustment.}

The first implication is implicit in the policy frameworks put forward in Ostry et al. (2010) and the subsequent institutional papers by the Fund. It is essentially that capital controlsand policies that mimic their effects - not act as a substitute for external adjustment, essentially because when they do in many cases the result forces unwarranted external adjustments on other countries. This means that discretion on their use is likely to be circumscribed, particularly when the currency is undervalued from a multilateral perspective.

A clear instance of this might be referred to as old-fashioned mercantilism. Country A uses capital controls cum intervention to pursue an undervalued exchange rate, and there is no obvious domestic distortion that justifies this behavior. This is the easiest case and most closely parallels the discussion in Ostry et al. (2010) and the subsequent institutional papers by the Fund. The undervaluation policy is not in the interest of the country itself and is costly for the rest of the world and so the capital controls that enable it should be proscribed.

Should all instances of inflow controls when the currency is undervalued be cause for concern? Not necessarily. For instance, inflow surges may exacerbate financial-stability concerns and measures to safeguard financial stability may be desirable from a prudential standpoint (even if they have an incidental impact on the volume of inflows). In these 
circumstances, and if another tool would not get the job done, controls may be considered even though the currency is undervalued, as discussed in Ostry et al. (2011).

Another case is the learning-by-doing externality. But here the bar must be much higher, both because undervaluation is not first-best from the country's own perspective, and because the multilateral implications are worse than under the first best policy (a production subsidy, which addresses the externality without distorting consumption decisions and the current account). As noted above, moreover, if multiple countries attempt to engineer undervaluation because of learning-by-doing externalities, the result is equivalent to an oldfashioned trade war (this is not the case for multiple countries imposing production subsidies which, while increasing production of tradables, has ambiguous effects on trade balances). Finally, multilateral scrutiny in such cases may also be justified because sustained one-way FX market intervention may have distortive effects on the current account that are much larger in practice than those associated with de jure capital controls (as discussed in Box 2).

We conclude that there is a presumption that undervaluation combined with inflow controls should raise red flags in most cases. As such, there would likely be scrutiny attached to situations in which countries adopt or sustain policies that are likely to have a substantial effect on capital inflows when their currencies are undervalued, and particularly when the intent of the controls is to support undervaluation (intention of course is very hard to establish, and is unlikely to be inferable from simple models of equilibrium exchange rates). The important point is that controls not act as a substitute for policies that would foster warranted external adjustment, and that countries act to strengthen their institutional and other policies so as to more safely intermediate foreign inflows.

\section{Implication 2: Countries should not seek to exploit market power.}

The second implication would stamp out behavior for strategic gain (e.g., terms of trade manipulation) as opposed to prudential reasons. As mentioned earlier, while it may seem farfetched that countries would use capital controls to manipulate the terms of trade, other policies - for example monetary policy - may have similar effects. As such, questions could be raised whenever there are spillovers from the policies of large creditor countries that tend to raise world interest rates (e.g., restrictions on outflows or policies that mimic such measures) or of large debtor countries that tend to lower world interest rates (e.g., quantitative easing). ${ }^{10}$ The primary purpose of the policies may not be strategic but the existence of spillovers/externalities would warrant some attention being paid to the policies in a multilateral context.

\footnotetext{
${ }^{10}$ Outflow restrictions by current account surplus (i.e., net source) countries keep the exchange rate more appreciated than otherwise, thus reducing the surplus; quantitative easing by current account deficit (i.e., net recipient) countries weakens the exchange rate, narrowing the deficit.
} 


\section{Implication 3: Capital flows should be managed in both source and recipient countries.}

The third implication involves coordination between recipient and source countries. While the former would welcome attacking the problem of volatile capital flows at both ends of the transaction, the incentives to coordinate for source countries are more complex. Our sense is that coordination is possible nonetheless for a number of reasons. First, spillovers between source and recipient countries are much larger than those among recipient countries, so a multilateral perspective would concentrate efforts at this margin more than at others. Second, while source countries may forego profits when they forego outflows, they may also reduce risk of incurring losses on their foreign lending as crises in recipient countries are less frequent. Third, to the extent that source countries are international creditors, there is a terms of trade gain associated with curtailing outflows that may offset some of the costs.

Coordination between source and recipient countries would seek to ensure that spillovers from source country policies (monetary, prudential-regulatory, etc.) are internalized by the source countries themselves. This would require monetary policy to give due attention to its international ramifications for capital flows, and regulatory policies to take account of the impact on financial stability in foreign jurisdictions. ${ }^{11}$ To the extent that there are costs of accommodative monetary policies (risks of inflationary expectations becoming unanchored; difficulties of shrinking central bank balance sheets), it would, in fact, be in the interests of the source country to take into account the cross-border spillovers since, otherwise, monetary policy would, from its own perspective, be excessively expansionary.

Regulation of cross-border activities of financial institutions headquartered in source countries is likely to provide an important element of multilateral oversight in this context. Specifically, while regulatory authorities are naturally responsible for maintaining financial stability at home, their mandate could be extended to cover activities of their financial institutions that contribute to instability elsewhere. Cooperation between regulators in recipient and source countries would be essential here, especially when the recipient country is being swamped by inflows that threaten to overwhelm the domestic regulatory framework. To the extent that a financial crisis in the recipient country inflicts losses on systemically important financial institutions in the source country, moreover, such cooperation would be in the interests of the source country regulators. Problems arise when the flows are too small to pose significant systemic risks in the source country, but large enough to be a major problem for recipient country regulators seeking to maintain financial stability.

\footnotetext{
${ }^{11}$ Limiting outflows from source countries may actually enhance the effectiveness of monetary policy on the domestic economy even as financial stability in recipient countries is buttressed.
} 


\section{Implication 4: Coordination may be needed to avoid capital control wars across recipient countries.}

The fourth implication would set limits to the use of capital controls (and related policies) when they create negative externalities for other recipient countries. When there are general surges of capital toward emerging market countries, and to the extent these elicit policy responses from multiple countries (because each is concerned about the macroeconomic or financial-stability risks), multilateral efforts could help ensure that countries imposing or intensifying controls calibrate them appropriately - that is, taking account of the possible response of other countries to the deflected flows. ${ }^{12}$ In practice, this means less intensive controls than would be the case if the flows were only going to one (or fewer) countries. Policy advice would be geared to helping recipient countries avoid a capital control war of escalating controls in response to deflected flows, recognizing that such a war would not be in their own interests, but also recognizing that multiple countries imposing/intensifying controls simultaneously (or in rapid sequence) is not necessarily indicative of a capital control war - it may simply be the appropriate response of each country to the excessive inflows it is facing. It is only a capital control war when controls escalation is in response to deflected flows.

\section{Conclusion}

The global financial crisis and its aftermath has reminded us that cross-border capital flows are subject to potentially extreme swings that wreak macroeconomic havoc and pose significant risks to financial stability. At the same time, foreign capital can help countries finance productive projects, build much-needed infrastructure, allocate resources efficiently, and expand employment opportunities. Much like motor cars that bring innumerable benefits, but also more than one million traffic-related deaths each year, cross-border capital flows may need some "rules of the road" to ensure smooth functioning and safe operation. Such multilateral coordination - if and when it is defined — will need to encompass a broader set of considerations than those discussed above; nevertheless, our hope is that this note will add to the analytical basis for such coordination in the future.

Building on welfare economics, and taking account of empirically relevant spillovers, our analysis suggests four implications. First, measures that restrict flows should not be allowed to substitute for external adjustment that is necessary from the country's own or the global perspective. This refers not only to the imposition of more stringent controls in the face of

\footnotetext{
${ }^{12}$ In a world with both destabilizing and beneficial flows (say "hot money" and FDI) and imperfect targeting of flows by capital controls, measures imposed by one country may actually deflect "good flows" to other countries. Our assumption here is that deflection of good flows - the collateral damage from the measure-is smaller than deflection of bad flows. In such case, coordination would indeed seek to lower the extent of capital controls across countries. If the opposite were true, then the inefficiency in the Nash equilibrium would point in the opposite direction, and coordination would actually seek to raise the level of capital controls.
} 
inflow surges, but also to the removal of structural impediments to inflows by countries with undervalued exchange rates as soon as this can be done without undermining domestic or global financial stability (or as soon as genuine "learning-by-doing" externalities have run their course). Second, measures by systemically important countries that distort the world interest rate merit multilateral scrutiny, and the pros and cons of such measures should be evaluated from a multilateral, not just the country's, perspective. Third, in imposing capital controls on inflows, recipient countries need to be mindful of possible deflection to other countries and their likely response. When there are general surges of capital to many countries, this means exercising some restraint in the imposition of capital controls. And fourth, greater coordination with systemically important source countries requires that they take account of policy spillovers and assume greater responsibility for ensuring that the financial institutions they supervise do not contribute to financial instability through their cross-border activities.

The foregoing implications are not to be interpreted as hard and fast multilateral "rules of the road," not least because fully specified norms of international behavior to guide policy advice in this area would need to take into account many factors that have been excluded by the simple models discussed here. This does not mean that multilateral institutions such as the IMF do not have a job to do in identifying spillovers that harm other countries, or in suggesting remedies or policy adjustments that go in the direction of internalizing the effects of such spillovers. The notion that international cooperation can mitigate the severity of boom-bust cycles in capital flows is one that goes back to the IMF's founding fathers. Both Keynes and White firmly held that rules for managing capital flows would be much more effective if movements of capital "could be controlled at both ends" than if a patchwork of unilateral policies ruled the day. And multilateral cooperation to foster global financial stability lies at the very heart of the purposes of the IMF. Global financial integration has progressed a long way in six decades, but multilateral oversight of both source and recipient countries to assist in the management of capital flow volatility remains a worthy objective, and one likely to be essential to safeguard the stability of the international monetary system. 


\section{REFERENCES}

Calvo, G., L. Leiderman, and C. Reinhart, 1993, "Capital Inflows and Real Exchange Rate Appreciation in Latin America: The Role of External Factors," IMF Staff Papers, Vol. 40 (1), pp. 108-51.

Coase, R., 1960, “The Problem of Social Cost," Journal of Law and Economics, 1, pp. 1-44.

Forbes, K., M. Fratzscher, T. Kostka, and R. Straub, 2011, "Bubble Thy Neighbor: Direct and Spillover Effects of Capital Controls," Mimeo, Massachusetts Institute of Technology.

Ghosh, A., and P. Masson, 1994, Economic Cooperation in an Uncertain World, (Blackwell).

Ghosh, A., and J. Kim, 2008, "Export Subsidies, Undervalued Exchange Rates, and Consumption Taxes-Some Equivalence Results of Relevance to Bretton Woods II," Mimeo (Washington: International Monetary Fund).

Ghosh, A., J. Kim, M. Qureshi, and J. Zalduendo, 2012, "Surges,” IMF Working Paper 12/22 (Washington: International Monetary Fund).

Habermeier, K., A. Kokenyne, and C. Baba, 2011, "The Effectiveness of Capital Controls and Prudential Policies in Managing Large Inflows," IMF Staff Discussion Note 11/14 (Washington: International Monetary Fund).

IMF, 2011a, Recent Experiences in Managing Capital Inflows-Cross-Cutting Themes and Possible Guidelines (Washington: International Monetary Fund).

_ 2011b, The Multilateral Aspects of Policies Affecting Capital Flows (Washington: International Monetary Fund).

Jeanne, O., A. Subramanian, and J. Williamson, 2012, Who Needs to Open the Capital Account? (Washington: Peterson Institute for International Economics).

Klein, M., 2012, “Capital Controls: Gates and Walls,” forthcoming, Brookings Papers on Economic Activity.

Korinek, A., 2010, "Regulating Capital Flows to Emerging Markets: An Externality View," University of Maryland Working Paper.

— A., 2011, "The New Economics of Prudential Capital Controls," IMF Economic Review, 59(3), pp. 523-61.

— A., 2012, "Capital Controls and Currency Wars," University of Maryland Working Paper.

Magud, N., C. Reinhart, K. Rogoff, 2011, "Capital Controls: Myth and Reality-A Portfolio Balance Approach,” NBER Working Paper No. 16805 (Cambridge, Massachusetts: National Bureau of Economic Research).

Ostry, J., A. Ghosh, K. Habermeier, M. Chamon, M. Qureshi, and D. Reinhardt, 2010, "Capital Inflows: The Role of Controls," IMF Staff Position Note 10/04 (Washington: International Monetary Fund). 
Ostry, J., A. Ghosh, K. Habermeier, L. Laeven, M. Chamon, M. Qureshi, and A. Kokenyne, 2011, "Managing Capital Inflows: What Tools to Use?" IMF Staff Discussion Note 11/06 (Washington: International Monetary Fund).

Ostry, J., A. Ghosh, and M. Chamon, 2012, “Two Targets, Two Instruments: Monetary and Exchange Rate Policies in Emerging Market Economies?” IMF Staff Discussion Note 12/01 (Washington: International Monetary Fund).

Reinhart, C., and V. Reinhart, 2008, "Capital Flow Bonanzas: An Encompassing View of the Past and Present," NBER Working Paper 14321 (Cambridge, Massachusetts: National Bureau of Economic Research).

Rodrik, D., 2008, “The Real Exchange Rate and Economic Growth: Theory and Evidence," Brookings Papers on Economic Activity: Fall 2008, pp. 365-412.

Taylor, M., and L. Sarno, 1997, "Capital Flows to Developing Countries: Long- and ShortTerm Determinants," World Bank Economic Review, Vol. 11 (3), pp. 451-70. 